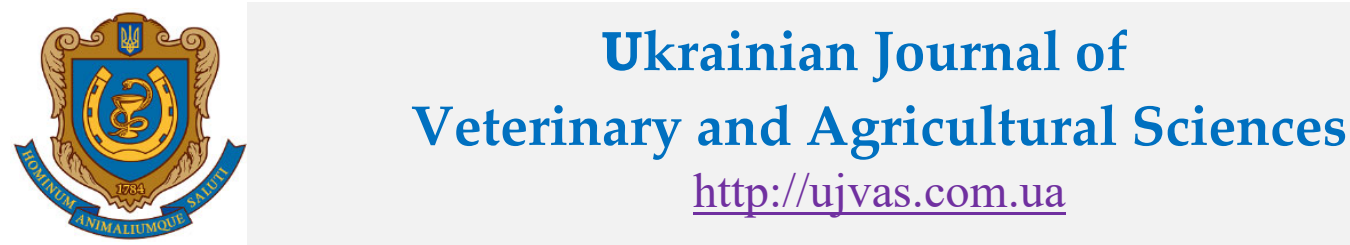

Stepan Gzhytskyi National University of Veterinary Medicine and Biotechnologies Lviv

\begin{tabular}{l|l|l} 
original article & UDC $638.124 .4: 606.4 \quad$ doi: $\mathbf{1 0 . 3 2 7 1 8 / u j v a s 4 - 2 . 0 3}$
\end{tabular}

\title{
Biotechnology of families' strength influence on the processes of sucrose inversion, dehydration and accumulation of monosaccharides
}

\author{
I. F. Bezpalyi
}

Bila Tserkva National Agrarian University, 8/1, Soborna Square, Bila Tserkva, 09117, Ukraine

\begin{tabular}{l} 
Article info \\
Received 19.04.2021 \\
Received in revised form \\
20.05 .2021 \\
Accepted 21.05.2021 \\
\hline Correspondence author \\
Ivan Bezpalyi \\
Tel.: +38-068-400-45-43 \\
E-mail: ifbezpalyi@ukr.net \\
\hline 2021 Bezpalyi I. This is an open- \\
access article distributed under the \\
terms of the Creative Commons \\
Attribution License, which permits \\
unrestricted use, distribution, and \\
reproduction in any medium, \\
provided the original author and \\
source are credited. \\
(cc)) Br
\end{tabular}

Contents

1. Introduction

2. Materials and methods....

4. Results and discussion ....... 14

References ..................... 16

\begin{abstract}
The purpose of the work is an experimental substantiation of biotechnological processes that ensure the maturation of honey during the processing of nectar by bees. During the whole period (7-9 days) of nectar treatment by bees there is a simultaneous partial dehydration of the liquid and biochemical transformations, among which the hydrolysis of sucrose and the accumulation of monosaccharides have the most significant effect on the quality of the mature product. In all series of experiments, the maturity of processed honey in the beehive at the water limit of less than $20 \%$ occurs after 5-6 days of treatment by bees. The mature product in terms of water content remains open in almost completely filled cells for another 3-5 days, slightly reducing the water content from 19.78$20.07 \%$ up to $16.40-18.38 \%$. Dynamic changes in the ratio of monosaccharides and sucrose in the process of nectar processing by bees, starting from the honey stomach during gathering from flowers to sealing in honeycomb cells have been detected. At the honey stomach-cell stage, a small amount of sucrose is hydrolyzed during the incomplete first day of processing and, as a rule, $0.48-4.11 \%$ of monosaccharides calculated relative to the dry weight of the product are added. Sucrose inversion is more intense during the next 5-6 days, when a total of $12.94-31.42 \%$ of splitted sugars are added, depending on their initial number and strength of families. The main processes of conversion of nectar into honey by bees are characterized by the advance of the reduction of water content in comparison with the splitting of sucrose and the accumulation of monosaccharides. According to the water content (less than $20 \%$ ), honey becomes suitable for pumping 3-5 days before it is sealed in the cells. The influence of the mass of bees of different families on the intensity of sucrose inversion in the cells and the accumulation of monosaccharides in the product has been experimentally proved. The maturity of honey in the ratio of sugars in the beehives of strong families is better than in weak ones.
\end{abstract}

Key words: bees, invertase, sucrose, monosaccharides, nectar, honey.

\section{Citation:}

Bezpalyi, I. F. (2021). Biotechnology of families' strength influence on the processes of sucrose inversion, dehydration and accumulation of monosaccharides. Ukrainian Journal of Veterinary and Agricultural Sciences, 4(2), 13-17.

\section{Introduction}

With the development of the social way of life, the bee family in the direction of creating an increasing supply of energy feed has improved the biotechnology of honey and reached such a height of productivity and depth of secrecy that humanity is impossible to establish artificial production of such a unique product (Avetysian \& Cherevko, 2001; Gätschenberger et al., 2013; Rabiee et al., 2015; Vishchur et al., 2016; 2019; Saranchuk et al., 2021). In the modern technology of obtaining honey, regardless of the level of industrialization of beekeeping, there are noted distinctions: 1) a set of techniques for keeping families in good condition to ensure the effective work of bees to gather nectar; 2) measures to assist bees in carrying out of complex biochemical transformations and physical changes in nectar; 3) processes of regulated and optimized influence on family productivity by selecting a mature product from the beehive (Razanov et al., 2010; Bondarenko \& Usachova, 2018; Wu et al., 2017; Arien et al., 2018; Kovalchuk et al., 2019).
Pumping of honey in the whole chain takes such a place that greatly affects its quality on the one hand and the realization of the potential of the family - on the other (Hartfelder, 2013; Kovalskyi et al., 2018). After all, every day of a relatively short period of intensive nectar treatment by bees, especially during a great forage, affects the amount of water extracted from it, changes in the ratio of sugars under the influence of sucrose inversion, as well as other transformations. They are associated with indicators of quality characteristics of marketable products (Adamchuk et al., 2015).

The results of researches available in the scientific literature (Ahanyn, 1985; Polishchuk, 2001; Kurta, 2016) and indicators of honey quality in official documents (DSTU 4497:2005, 2007) do not fully present the features of domestic varieties.

In order to comply with the requirements of the technology of obtaining high quality competitive honey, sufficiently mature in terms of residual water content, the amount of monosaccharides transferred from nectar and accumulated as a result of sucrose splitting during processing by bees, it 
is important to know in what condition it is in the sealed cells of the honeycomb and what changes precede it.

Finding out the dynamics of changes in the ratio of sucrose and monosaccharides and water content in nectar throughout the period from absorption into the honey stomach of the bee-collector to the sealing of honey in the cells, the duration of transformation into a mature product is important in optimizing technology and studying of its properties. Therefore, the study of gradual changes in chemical composition and partial dehydration and their duration in the process of nectar processing by bees is of great current interest for scientific knowledge of the processes in the family and increase of honey production.

The purpose of the work is an experimental substantiation of biotechnological processes that ensure the maturation of honey during the processing of nectar by bees.

\section{Materials and methods}

The experiments were conducted at the apiary of Bila Tserkva National Agrarian University in 2017-2018. The bee families of the Ukrainian steppe breed were used in the work. To expand our understanding of the role of the family in extracting excess water from nectar, invertion of sucrose, and the bee organism during the maturation of honey, we have conducted a comparative study of strong and weak families. They were selected on the principle of analogues of three in each of the two groups. The studies were performed on honey gathering from white acacia by sampling nectar from honey stomach of bees caught when they entered the hive, then on the same evening and every two days of maturation in honeycomb cells before sealing the honey on the $9^{\text {th }}$ day with wax caps. Sampling of honey, analysis of physicochemical parameters was carried out according to DSTU 4497:2005 "Natural honey. Technical conditions" (DSTU 4497:2005, 2007).

\section{Results and discussion}

The initial water content of the gathered nectar in the bees' honey stomachs, collected near the hive flight at 1011 o'clock, did not differ significantly between strong $(38.95 \%)$ and weak families $(41.95 \%)$ (Table 1$)$. In the evening of the same day, samples of fresh nectar taken from honeycomb cells showed water of 25.60 and $26.40 \%$, respectively. The difference in the amount of water withdrawn by bees during the partial day was $13.35 \%$ in the control group and $15.55 \%$ in the experimental group. During the following days, the dehydration process slowed down. Its intensity for the two-day period before sealing the cells with honey decreased up to $0.6-1.2 \%$.

It is noteworthy that the product treated by bees in terms of water content reached almost full maturity in five days dehydration exceeded $20 \%$ both in strong and weak families. Bees reduced the water content of honey up to 19.4 and $19.8 \%$, respectively. However, such honey bees do not cover with wax caps, it remains in the cells in a state accessible to them for another four days.

\section{Table 1}

Dynamics of dehydration and inversion of sucrose by bees of strong and weak families, $\mathrm{n}=3$

\begin{tabular}{|c|c|c|c|}
\hline \multirow{2}{*}{$\begin{array}{c}\text { Days of after-maturity } \\
\text { (honey stomach - honeycomb) }\end{array}$} & \multicolumn{3}{|c|}{ Content in the natural product, $\%\left(\bar{X} \pm \mathrm{S}_{\bar{X}}\right)$} \\
\hline & water & sucrose & monosaccharides \\
\hline \multicolumn{4}{|c|}{ Strong families (control group) } \\
\hline Bee's honey stomach & $38.95 \pm 0.283$ & $23.57 \pm 0.494$ & $34.37 \pm 0.513$ \\
\hline 1 -st & $25.60 \pm 0.368$ & $28.16 \pm 0.545$ & $42.25 \pm 0.613$ \\
\hline 3-rd & $21.30 \pm 0.434$ & $23.53 \pm 1.077$ & $51.96 \pm 1.131$ \\
\hline 5-th & $19.40 \pm 0.294$ & $14.18 \pm 0.356$ & $63.21 \pm 0.580$ \\
\hline 7-th & $17.00 \pm 0.507$ & $6.24 \pm 0.372$ & $73.21 \pm 1.235$ \\
\hline 9-th (sealed) & $16.40 \pm 0.216$ & $4.95 \pm 0.254$ & $75.64 \pm 0.810$ \\
\hline \multicolumn{4}{|c|}{ Weak families (experimental group) } \\
\hline Bee's honey stomach & $41.95 \pm 0.301$ & $24.32 \pm 0.315$ & $30.53 \pm 0.287$ \\
\hline 1 -st & $26.40 \pm 0.542$ & $30.79 \pm 0.586$ & $38.74 \pm 0.276$ \\
\hline 3-rd & $23.70 \pm 0.450$ & $27.32 \pm 0.308$ & $45.76 \pm 0.312$ \\
\hline 5-th & $19.80 \pm 0.348$ & $22.65 \pm 0.404$ & $54.21 \pm 0.383$ \\
\hline 7-th & $18.40 \pm 0.439$ & $15.64 \pm 0.344$ & $62.26 \pm 0.880$ \\
\hline 9-th (sealed) & $17.20 \pm 0.221$ & $10.26 \pm 0.493$ & $68.78 \pm 0.826$ \\
\hline
\end{tabular}

During all this time, $2.6-3.0 \%$ of water is removed from it, and in the last days before sealing $0.3-0.4 \%$ per day. It should be noted that at the final stage of honey production by bees, differences in the intensity of partial dehydration between groups of families were not established.

Thus, it has been experimentally proved that a honeycomb filled with nectar in five days is qualitatively close to full maturity in terms of water content, but bees keep it unsealed until the ninth day both in strong and weak families. Throughout the whole period, they actively process the manufactured product.

Simultaneously with the study of the dynamics of dehydration in the experimental families, samples were taken to determine the content of sucrose and monosaccharides. The processed experimental data are given in Table 1 next to water content indices.

It was found that the relative amount of sucrose in fresh nectar does not change significantly. Only on the fifth day, this figure decreased from 23 to $14 \%$. However, this stability is associated with the thickening of the product processed by bees, which is accompanied by two processes - the inversion (splitting) of sucrose and the concentration of sugars. During the first day, when the most water is removed from the nectar, these processes do not balance the outwardly noticeable stability and the relative amount of sucrose even exceeds the initial percentage. Thus, in strong families, the rate of sucrose nectar of bee's honey stomach because of thickening by the end of the day in the honeycomb changed 
from 23.57 to $28.16 \%$, and in weak one -24.32 and $30.79 \%$ respectively (Fig. 1 ).

A comparative analysis according to the sucrose and water content of the product showed that on the 5th day of maturation in strong families the inversion process is ahead of the dehydration process, while in weak families it occurs only on the $7^{\text {th }}$ day. Yet again, the fact calls attention that in the control group, reduction of disaccharide to the $7^{\text {th }}$ day is more intense and it decreases sharply to the $9^{\text {th }}$ day of maturation. At the same time, in the experimental group of families there is a uniform decrease in sucrose under the intense influence of bees.

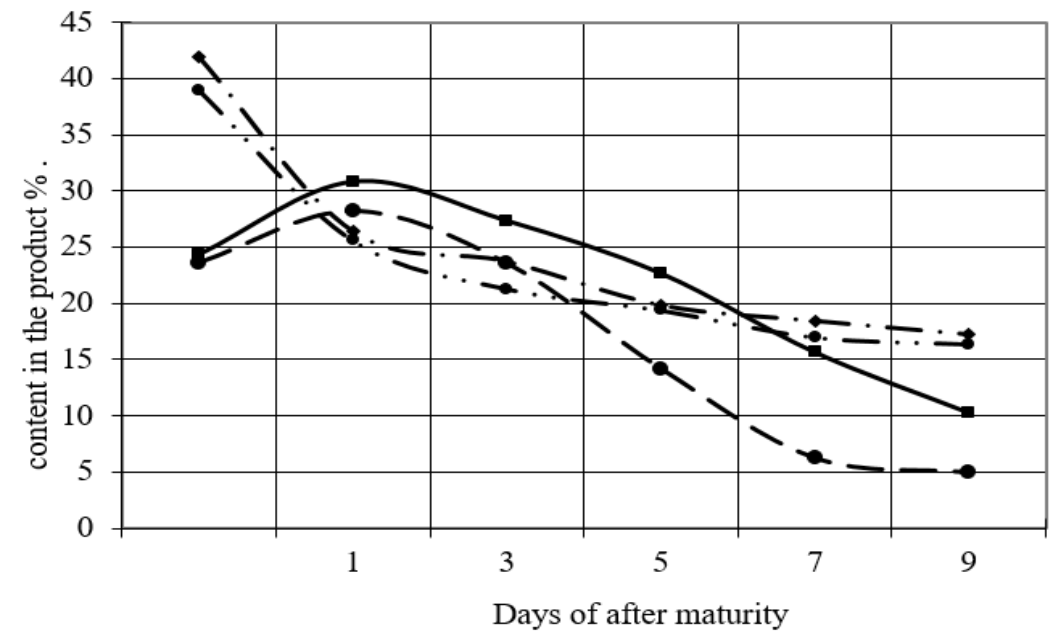

Fig. 1. Comparative evaluation of the process of nectar dehydration of in the honeycomb of strong and weak families, along with the inversion of sucrose:

dynamics of water content in the product from the honeycomb of strong families;
- dynamics of water content in the product from the honeycomb of weak families;
- dynamics of sucrose inversion in the product from the honeycomb of strong families;

It was found that the process of sucrose inversion occurs faster in strong families than in weak ones and this difference is statistically significant with a probability of $\mathrm{P}>0,999$.

Features of sucrose inversion in nectar are more fully revealed according to studies of monosaccharides. Their number in the product processed by bees is characterized by constant growth from the time of its processing in a honey stomach to sealing in a honeycomb. However, the result of the accumulation of invert sugar in families of different strengths is markedly different. According to our data, fresh (in the sealed state) honey in strong families contains $75.63 \%$ of monosaccharides, in weak ones $-68.78 \%$. Differences between the families of the two groups were also found in terms of the relative increase in glucose and fruc- tose. In strong bee families, the inversion increased after the third day of nectar treatment (increase of 10-11.25\%), and in weak ones - it remained at the previous level, not exceeding $8.45 \%$. As a result, in case of insufficient number of bees, the families sealed honey, which contained $10.28 \%$ of sucrose, and in strong families this indicator decreased to $4.95 \%$ with a probability of $\mathrm{P}>0.999$.

The splitting of sucrose nectar during the after maturation of honey occurs under the influence of the enzyme inverses, which is the part of the secretion of the hypo pharyngeal glands of older worker-bees. Therefore, in an experiment on strong and weak families, we selected worker-bees from each honeycomb to determine the inverting capacity of their glands. The obtained results of laboratory analysis are given in table. 2 .

Table 2

Inverting ability of bee glands during honey gathering from white acacia, $n=3$

\begin{tabular}{ccccc}
\hline \multirow{2}{*}{ Group of families } & \multicolumn{4}{c}{ Glucose was formed under the influence of the enzyme for 100 bees, mg } \\
\cline { 2 - 5 } & $\bar{X} \pm \mathrm{S}_{\bar{X}}$ & $\mathrm{lim}$ & $\mathrm{Cv}, \%$ & $\mathrm{td}$ \\
\hline Strong (control) & $380.7 \pm 6.21$ & $361.5-415.8$ & 7.99 & - \\
Weak (experimental) & $96.1 \pm 3.27$ & $83.7-114.2$ & 16.68 & 40.53 \\
\hline
\end{tabular}

Research data show that within 3 hours of inverses action from 100 bees of the control group produces in average of $380.7 \mathrm{mg}$ of glucose per $50 \%$ sucrose solution, i.e. almost 4 times more than at bees from the families of the experimental group. Thus, bees of strong and weak families showed different inverting ability of the pharyngeal glands. The difference between groups of families according to this indicator is highly probable $(\mathrm{P}>0.999)$.
We have compared the data of the sugar content in mature honey with the inverting ability of bees in the control and experimental groups. The results are shown in the form of a diagram in Fig. 2.

The results of the experiment explain this by the fact that with a small number of bees, families are involved in gathering and producing honey from younger age groups, in which the inversion function has not reached the maximum, which is typical for flying bees of older age. 


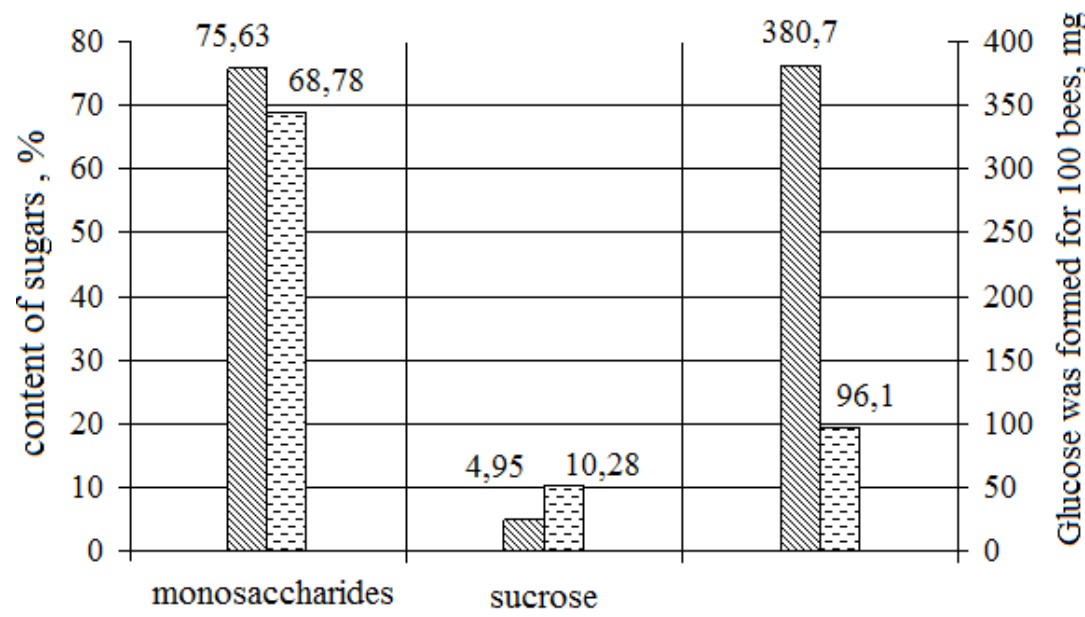

Fig.2. Comparison of data of sugars content in mature honey and inverting ability of bees: - indicators of strong families;

Bees from strong families have a higher inverting ability, so the produced mature honey had $6.85 \%$ more of monosaccharides and per $5.33 \%$ less of sucrose than the sealed product in weak families. At the same time, $18.2 \mathrm{~kg}$ of acacia honey was obtained from the families of the control group after pumping out the honeycombs, and $8.6 \mathrm{~kg}$ from the families of the experimental group.

Comparative data of the dynamics of dehydration and inversion of sucrose in the process of nectar processing show that bee families of different strengths almost equally intensively reduce its water content, but inversely carry out the inversion of sucrose. Fresh honey pumped from strong families has a better maturity in terms of simple sugars than that one obtained from weak families.

Thus, bee families, adapting to the procurement of honey in the evolution of the social way of life, have acquired the ability to regulate interfamilial loads by fluent changes of functions among working individuals. These phenomena have been previously detected in other foraging bees.

\section{Conclusions}

In all series of experiments, the maturity of processed honey in the beehive at the water limit of less than $20 \%$ occurs after 5-6 days of treatment by bees. The mature product in terms of water content remains open in almost completely filled cells for another 3-5 days, slightly reducing the water content from $19.78-20.07 \%$ to 16.40 $18.38 \%$. The influence of the mass of bees of different families on the intensity of sucrose inversion in the cells and the accumulation of monosaccharides in the product has been experimentally proved. The maturity of honey in the ratio of sugars in the beehives of strong families is better than in weak ones. During the honey gathering from white acacia bees of strong families seal in the cells honey, which contains monosaccharides $75.63 \%$, in weak families $68.78 \%$, and the ratio of sucrose and monosaccharides in their amount was in the dry mass, $0.06: 0.94$ and $0.13: 0.87$ respectively.

\section{References}

Adamchuk, L. O., Bilotserkivets, T. I., Henhalo, N. O., \& Mykhalska, O. M. (2015). Otsiniuvannia medu za pokaznykamy yakosti vidpovidno do chynnykh normatyviv. Naukovyi visnyk NUBIP Ukrainy, 223, 52-57 (in Ukrainian).

Ahanyn, A. V. (1985). Med i eho issledovaniye. Saratov: Izdatelstvo Saratovskoho universyteta (in Russian).

Arien, Y., Dag, A., \& Shafir, S. (2018). Omega-6:3 Ratio More Than Absolute Lipid Level in Diet Affects Associative Learning in Honey Bees. Front. Psychol, 9, 1-8. doi: 10.3389/fpsyg.2018.01001.

Avetysian, H. A., \& Cherevko, Yu. A. (2001). Pchelovodstvo. M.: YRPO; Izd. Tsentr Akademyia (in Russian).

Bondarenko, O. M., \& Usachova, V. Ie. (2018). Navchalnometodychnyi posibnyk vykonannia laboratornykh zaniat $\mathrm{z}$ dystsypliny "Tekhnolohiia vyrobnytstva produktsii bdzhilnytstva". Poltava (in Ukrainian).

DSTU 4497:2005 (2007). Honey is natural. Specifications. K.: Derzhspozhyvstandart of Ukraine (in Ukrainian).

Gätschenberger, H., Azzami, K., Tautz, J., \& Beier, H. (2013). Antibacterial Immune Competence of Honey Bees (Apis mellifera) Is Adapted to Different Life Stages and Environmental Risks. PLoS ONE, 8, 6. doi: 10.1371/journal.pone.0066415.

Hartfelder, K. (2013). Physiology and biochemistry of honey bees. Journal of Apicultural Research, 3, 504-508.

Kovalchuk, I., Dvylyuk, I., Lecyk, Y., Dvylyuk, I., \& Gutyj, B. (2019). Physiological relationship between content of certain microelements in the tissues of different anatomic sections of the organism of honey bees exposed to citrates of argentum and cuprum. Regulatory Mechanisms in Biosystems, 10(2), 177181. doi: $10.15421 / 021926$.

Kovalskyi, Yu., Gucol, A. Gutyj, B., Sobolev, O., Kovalska, L., \& Mironovych, A. (2018). Features of histolism and hystogenesis in the vital temperature range in the organism of honey bee (Apis mellifera L.) in the postembrional period. Ukrainian Journal of Ecology, 8(2), 301-307. doi: 10.15421/2018_342.

Kurta, S. A. (2016). Pryrodni vuhlevodiv ta polisakharydy. Navchalnyi posibnyk. Prykarpatskyi natsionalnyi universytet imeni Vasylia Stefanyka. Ivano-Frankivsk (in Ukrainian).

Polishchuk, V. P. (2001). Bdzhilnytstvo. Lviv, Ukrainskyi pasichnyk (in Ukrainian).

Rabiee, F., Modaresi, M., \& Gheisari, A. (2015). The effect to various oleic acid levels on reproductive parameters in queen bee. Der Pharmacia Lettre, 7(12), 326-331. URL: https://www.scholarsresearchlibrary.com/articles/the-effect-tovarious-oleic-acid-levels-on-reproductive-parameters-in-queenbee.pdf.

Razanov, S. F., Bezpalyi, I. F., Bala, V. I., \& Donchenko, T. A. (2010). Tekhnolohiia vyrobnytstva produktsii bdzhilnytstva. K.: Ahrarna osvita (in Ukrainian).

Saranchuk, I. I., Vishchur, V. Ya., Gutyj, B. V., Klim, O. Ya. (2021). Effect of various amounts of sunflower oil in feed addi- 
tives on breast tissues' functional condition, reproductivity, and productivity of honey bees. Ukrainian Journal of Ecology, 11(1), 344-349. doi: 10.15421/2021 51.

Vishchur, V. Y., Gutyj, B. V., Nischemenko, N. P., Kushnir, I. M., Salata, V. Z., Tarasenko, L. O., Khimych, M. S., Kushnir, V. I., Kalyn, B. M., Magrelo, N. V., Boiko, P. K., Kolotnytskyy, V. A., Velesyk, T., Pundyak, T. O., \& Gubash, O. P. (2019). Effect of industry on the content of fatty acids in the tissues of the honey-bee head. Ukrainian Journal of Ecology, 9(3), 174-179. doi: $10.15421 / 2019727$
Vishchur, V. Y., Saranchuk, I. I., \& Gutyj, B. V. (2016). Fatty acid content of honeycombs depending on the level of technogenic loading on the environment. Visnyk of Dnipropetrovsk University. Biology, ecology, 24(1), 182-187. doi: 10.15421/011622.

Wu, Y., Zheng, H., Corona, M. et al. (2017). Comparative transcriptome analysis on the synthesis pathway of honey bee (Apis mellifera) mandibular gland secretions. Scientific Reports, 7(1), 4530. doi: 10.1038/s41598-017-04879-z. 